\title{
ANALISIS TINGKAT PENGETAHUAN PEMAHAMAN DAN KESADARAN PEMILIK USAHA KOS TENTANG PAJAK KOS DI KECAMATAN LOWOKWARU KOTA MALANG
}

\author{
Luh Dina Ekasari ${ }^{1}$, Kristina Lodan ${ }^{2}$ \\ 1)Staf Pengajar Program Studi Akuntansi Fakultas Ekonomi Universitas Tribhuwana Tunggadewi \\ 2)Mahasiswa Program Studi Akuntansi Fakultas Ekonomi Universitas Tribhuwana Tunggadewi
}

\begin{abstract}
ABCTRAC
Taxes are very important in increasing tax revenues in Malang City. Tax rates of types of boarding houses with a number of rooms more than 10 (ten) are set at 5\% (five percent). Increased tax revenue is supported by knowledge, understanding, and awareness of taxes carried out by Plasya boarding owners on taxation. The purpose of this study is to find out the knowledge, understanding and reflection of boarding house business owners about boarding tax in Malang Lowokwaru Salvation as a whole. The research conducted is research using quantitative methods. Determination of this research sample using the pruposive sampling method. The sample was obtained as many as 40 Kos Taxpayers in Lowokwaru District, Malang City. The data used are questionnaires and documentation. The data analysis method used is multiple linear regression using the SPSS program. The results of the study prove that partially (each) knowledge of the boarding tax amounted to (3.132), the tax on the boarding tax amounted to (2.817) and awareness of the boarding tax amounted to (3.623). Overall knowledge, understanding and awareness of boarding taxes on business owners in Lowokwaru District, Malang City is $61.2 \%$. What needs to be done by Kos Taxpayers is that it is appropriate to pay taxes such as timely taxes to increase and increase tax returns to improve the development and economy of Indonesia.
\end{abstract}

Keywords: Awareness, Kos Tax, Knowledge, Understanding

\begin{abstract}
ABSTRAK
Pajak Kos berperan penting dalam peningkatan penerimaan pajak di Kota Malang. Tarif Pajak jenis rumah kos dengan jumlah kamar lebih dari 10 (sepuluh) ditetapkan sebesar 5\% (lima persen). Peningkatan penerimaan pajak kos didukung oleh adanya pengetahuan, pemahaman dan kesadaran tentang pajak yang dimiliki pemilik kos sehingga patuh terhadap perpajakan. Tujuan penelitian ini untuk mengetahui pengaruh pengetahuan, pemahaman dan kesadaran pemilik usaha kos tentang pajak kos diKecamatan Lowokwaru Kota Malang secara parsial. Penelitian yang dilakukan merupakan penelitian dengan mengunakan metode kuantitatif. Penentuan sampel penelitian ini menggunakan metode pruposive sampling sehingga didapatkan sampel sebanyak 40 Wajib Pajak Kos di Kecamatan Lowokwaru Kota Malang.Teknik pengumpulan data yang digunakan oleh peneliti adalah kuesioner dan dokumentasi. Metode analisa data yang di gunakan yaitu regresi linier berganda dengan mengunakan program SPSS. Hasil penelitian membuktikan bahwa secara parsial (masing-masing) pengetahuan berpengaruh terhadap pajak kos sebesar $(3,132)$, pemahaman berpengaruh terhadap pajak kos sebesar $(2,817)$ dan kesadaran berpengaruh terhadap pajak kos sebesar $(3,623)$. Secara keseluruhan pengetahuan, pemahaman dan kesadaran berpengaruh terhadap pajak kos pada pemilik usaha kos di Kecamatan Lowokwaru Kota Malang sebesar 61,2\%. Adapun yang perlu dilakukan Wajib Pajak Kos yaitu patuh dalam pembayaran pajak seperti membayar pajak tepat waktu sehingga mambantu berperan serta dalam meningkatkan hasil pajak untuk meningkatkan pembangunan dan perekonomian Indonesia.
\end{abstract}

Kata Kunci: Kesadaran, Pajak Kos, Pengetahuan, Pemahaman 


\section{PENDAHULUAN}

Pajak merupakan salah satu sumber dari sekian banyak penerimaan pemerintah Indonesia baik itu pemerintah pusat maupun pemerintah daerah digunakan untuk membiayai pembangunan didaerah yang bertujuan untuk dapat membiayai dan memajukan daerah yang ditempuh dengan kebijakan pada pengoptimalisasian penerimaan pajak, dimana setiap orang wajib membayar pajak sesuai dengan kewajibannya. Salah satu pendapatan hasil daerah yaitu berasal dari pajak daerah, yaitu pajak yang ditetapkan oleh daerah untuk kepentingan pembiayaan rumah tangga pemerintahan daerah tersebut.

Di Indonesia dewasa ini dikenal berbagai jenis pajak dan diberlakukan meliputi berbagai aspek kehidupan masyarakat. Ditinjau dari lembaga pemungutnya, pajak dibedakan menjadi dua, yaitu pajak pusat dan pajak daerah. Pembagian jenis pajak ini di Indonesia terkait dengan hierarki pemerintahan yang berwenang menjalankan pemerintahan dan memungut sumber pendapatan negara, khususnya pada masa otonomi daerah dewasa ini.

Berdasarkan Undang-Undang Nomor 28 Tahun 2009 tentang Pajak Daerah di Indonesia dibagi menjadi 2 (dua) jenis Pajak, yaitu Pajak Provinsi dan Pajak Kabupaten atau Kota. Pajak Provinsi terbagi atas 5 (lima) jenis pajak yang terdiri atas Pajak Kendaraan Bermotor, Bea Balik Nama Kendaraan Bermotor, Pajak Bahan Bakar Kendaraan
Bermotor, Pajak Air Permukaan, serta Pajak Rokok. Sdangkan Pajak Kabupaten/Kota yang dibagi dalam 11 (sebelas) jenis pajak, terdiri atas Pajak Hotel, Pajak Restoran, Pajak Hiburan, Pajak Reklame, Pajak Penerangan Jalan, Pajak Mineral bukan Logam dan Batuan, Pajak Parkir, Pajak Air Tanah, Pajak Sarang Burung Walet, Pajak Bumi dan Bangunan Perdesaan dan Perkotaan serta Bea Perolehan Hak atas Tanah dan Bangunan (BPHTB).

Pembagian Pajak Daerah ini dilakukan berdasarkan kewenangan pengenaan dan pemungutan masing-masing jenis pajak daerah pada wilayah administratif Provinsi atau Kabupaten atau Kota yang bersangkutan. Namun Pajak Daerah tersebut tidak semua terlaksana secara baik dan efesien. Hal ini dikarenakan dibeberapa pemerintah daerah tersebut penerimaan yang potensial hanya bersumber dari beberapa jenis pajak saja, misalnya Pajak Hotel, Pajak Restoran, Pajak Hiburan atau Pajak Reklame saja. Pendapatan Asli Daerah merupakan penerimaan dari pungutan pajak daerah, retribusi daerah, hasil dari perusahaan daerah, penerimaan dari dinas-dinas dan penerimaan lainnya yang termasuk dalam Pendapatan Asli Daerah (PAD) yang bersangkutan, dan merupakan pendapatan daerah yang sah. Semakin tinggi peranan Pendapatan Asli Daerah (PAD) dalam pendapatan daerah merupakan cermin keberhasilan usaha-usaha atau tingkat kemampuan dalam pembiayaan 
penyelenggaraan pemerintahan dan pembangunan.

Salah satu daerah yang menjadi penyumbang baik pajak daerah adalah Kota Malang. Kota Malang dikenal sebagai Kota Pendidikan dan Pariwisata. Malang sebagai kota pendidikan dapat dilihat dengan adanya banyak perguruan tinggi negeri maupun swasta yang memiliki fasilitas pendidikan memadai yang menjadikan Kota Malang sebagai Kota Pendidikan dimana tempat para pelajar yang berasal dari luar Kota Malang datang untuk menimbah ilmu. Selain sebagai kota pendidikan, Malang juga dikenal sebagai kota pariwisata. Hal tersebut dapat dilihat bahwa Malang memiliki banya tempat pariwisata mulai dari wisata alam, kuliner, wisata budaya maupun wisata buatan. Ditunjang dengan keadaan geografis alam yang sedemikian rupa serta udara yang sejuk menjadikan Malang sebagai salah satu destinasi wisatawan lokal maupun mancanegara. Kota Malang yang terkenal sebagai kota pendidikan dan pariwisata tersebut menjadikan pertumbuhan ekonomi di Kota Malang cukup potensial. Sehingga banyak juga pendatang yang menetap sementara atau permanen untuk menimba ilmu, berbisnis, berwisata, dan lain sebagainya.

Berkembangnya perekonomian dan pendidikan di Kota Malang menimbulkan banyaknya jumlah pendatang yang sebagian besar adalah mahasiswa. Perguruan tinggi yang tersebar diseluruh wilayah Kota Malang seakan-akan menjadi tarikan medan magnet yang sangat kuat bagi para putra-putri bangsa dalam mengejar pendidikannya. Diperkirakan sebagian besar mahasiswa yang menuntut ilmu adalah mahasiswa yang berasal dari luar Kota Malang.

Kenaikan jumlah penduduk dan dalam hal ini adalah para mahasiswa, akan berimplikasi pada naiknya permintaan akan hunian sementara. Hal ini dikarenakan setiap tahunnya, lebih dari setengah mahasiswa tahun ajaran baru berasal dari luar kota atau daerah. Sehingga dimungkinkan bagi para mahasiswa membutuhkan hunian sebagai tempat tinggal sementara selama menimba ilmu di perguruan tinggi. Dan tidak dapat dipungkiri lagi keberadaan akan rumah kos sebagai tempat tinggal sementara sangat dibutuhkan dan semakin meningkat. Sektor ini dinilai bisnis yang cukup menjanjikan kedepannya. Sehingga banyak pengusaha rumah kos bermunculan yang merupakan penduduk asli setempat hingga penduduk dari luar Kota Malang datang untuk berinvestasi. Melihat kondisi tersebut tentu saja menjadi sangat potensial terhadap penerimaan pajak baik daerah maupun pusat.

Warga asli Kota Malang pun melihat peluang usaha ini dengan mendirikan bangunan yang sengaja dibuat untuk menjadi hunian sementara. Berbagai macam pilihan hunian tersedia di seluruh wilayah Kota Malang, mulai dari hotel, losmen, pesanggrahan, rumah kontrakan serta koskosan. Dari sekian pilihan tersebut kos-kosan 
menjadi pilihan utama karena harganya yang relatif murah serta lebih dekat dengan kampus dibanding hunian yang lainnya. Harga yang ditawarkan bervariasi, dari kisaran harga termurahnya sekitar Rp3.500.000,00 sampai yang termahal dengan harga diatas Rp10.000.000,00.

Dari hasil penelitian yang dilakukan oleh Prawagis (2016) menyimpulkan bahwa pelaksanaan self assement system belum biasa diterapkan oleh wajib pajak orang pribadi terutama pemilik usaha kos-kosan karena mereka sering kali tidak melaporkan pajak penghasilan. Sedangkan dari hasil penelitian Ananda (2015) menemukan bahwa para pemilik kos tidak paham dengan peraturan pajak penghasilan atas persewaan tanah dan bangunan.

Berdasarkan hal tersebut di atas dalam penelitian ini peneliti ingin mengetahui tingkat dan menganalisis tingkat pemahaman dan kesadaran wajib pajak khususnya usaha kos-kosan sebagai Pendapatan Asli Daerah (PAD) kota Malang.

Tujuan penelitian ini untuk mengetahui pengaruh pengetahuan, pemahaman dan kesadaran pemilik usaha kos tentang pajak kos di Kecamatan Lowokwaru Kota Malang secara parsial.

\section{METODE PENELITIAN}

Penelitian yang dilakukan merupakan penelitian dengan mengunakan metode kuantitatif. Penentuan sampel penelitian ini menggunakan metode pruposive sampling sehingga didapatkan sampel sebanyak 40 Wajib Pajak Kos di Kecamatan Lowokwaru Kota Malang. Teknik pengumpulan data yang digunakan oleh peneliti adalah kuesioner dan dokumentasi. Metode analisa data yang di gunakan yaitu regresi linier bergandadengan mengunakan program SPSS.

\section{HASIL DAN PEMBAHASAN}

\section{Analisis Regresi Linear Berganda}

Analisis regresi linear berganda digunakan untuk menganalisis analisis tingkat pemahaman pemilik usaha kos tentang Pajak Kos di Kecamatan Lowokwaru Kota Malang. Hasil uji regresi linear berganda diketahui pada tabel berikut:

Tabel 1: Uji Regresi Linear Berganda

\begin{tabular}{ccc}
\hline Variabel & $\begin{array}{c}\text { B } \\
\text { Unstandardized } \\
\text { Coefficients }\end{array}$ & Keterangan \\
\hline Constant & 10,098 & Positif \\
$\left(\mathrm{X}_{1}\right)$ & 0,642 & Positif \\
$\left(\mathrm{X}_{2}\right)$ & 0,617 & Positif \\
$\left(\mathrm{X}_{3}\right)$ & 0,703 & Positif \\
\hline \multicolumn{3}{c}{$R$ square $=0,612$} \\
\hline
\end{tabular}

Sumber: Data primer diolah, 2018

Berdasarkan tabel 1 dapat dibuat persamaan regresi untuk mengukur tingkat pemahaman pemilik usaha kos tentang Pajak Kos berdasarkan variabel pengetahuan $\left(\mathrm{X}_{1}\right)$, variabel pemahaman $\left(\mathrm{X}_{2}\right)$ dan variabelkesadaran $\left(\mathrm{X}_{3}\right)$, digunakanpersamaan regresi sebagai berikut:

$$
\begin{aligned}
& Y: a+b_{1} X_{1}+b_{2} X_{2}+b_{3} X_{3}+e \\
& Y: 10,098+0,642 X_{1}+0,617 X_{2}+0,703 X_{3}+e
\end{aligned}
$$


Berdasarkan persamaan regresi dapat diartikan bahwa, nilai variabel Pajak Kos (Y) sebesar nilai konstanta sebanyak 10,098, sedangkan untuk keseluruhan nilai variable sebanyak 12,060, dengan demikian makna dari nilai regresi masing-masing variabel sebagai berikut:

$\mathrm{Y}=$ variabel terikat yang nilainya akan diprediksi oleh variabel Pajak Kos (Y) yaitu variabel pengetahuan $\left(\mathrm{X}_{1}\right)$, variabel pemahaman $\left(\mathrm{X}_{2}\right)$ dan variable kesadaran $\left(\mathrm{X}_{3}\right)$.

$\mathrm{X}_{1}=$ koefisien regresi $\left(\mathrm{X}_{1}\right)$ sebesar 0,642 dengan tanda menyatakan bahwa variable pengetahuan $\left(\mathrm{X}_{1}\right)$ mempunyai pengaruh positif terhadap variabel Pajak $\operatorname{Kos}(\mathrm{Y})$

$\mathrm{X}_{2}=$ koefisien regresi $\left(\mathrm{X}_{2}\right)$ sebesar 0,617 dengan tanda menyatakan bahwa variabel pemahaman $\left(\mathrm{X}_{2}\right)$ mempunyai pengaruh positif terhadap variabel Pajak Kos (Y)

$\mathrm{X}_{3}=$ koefisien regresi $\left(\mathrm{X}_{3}\right)$ sebesar 0,703 dengan tanda menyatakan bahwa variable kesadaran $\left(\mathrm{X}_{3}\right)$ mempunyai pengaruh positif terhadap variabel Pajak $\operatorname{Kos}(\mathrm{Y})$

Hasil analisa didapakan nilai $r$ square sebesar 0,612 artinya variabel pengetahuan $\left(\mathrm{X}_{1}\right)$, variabel pemahaman $\left(\mathrm{X}_{2}\right)$ dan variabelkesadaran $\left(\mathrm{X}_{3}\right)$ berpengaruh terhadap pajak kos (Y) pada pemilik usaha kos di Kecamatan Lowokwaru Kota Malang sebesar $61,2 \%$ dan sisanya sebesar 0,388 atau $38,8 \%$ dipengaruhi oleh variabel lain yang tidak diteliti.

\section{Pengujian Hipotesis (Uji t / Parsial)}

Uji $\mathrm{t}$ dilakukan untuk mengetahui besarnya pengaruh dari masing-masing variabel pengetahuan $\left(\mathrm{X}_{1}\right), \quad$ variabel pemahaman $\left(\mathrm{X}_{2}\right)$ dan variabel kesadaran $\left(\mathrm{X}_{3}\right)$ terhadap pajak kos (Y) pada pemilik usaha kos di Kecamatan Lowokwaru Kota Malang, adapun besarnya nilai masing-masing pengaruh dari variabel bebas terhadap variabel terikat dapat diketahui pada tabel berikut:

Tabel 2: Hasil Uji t

\begin{tabular}{cccc}
\hline Variabel & t hitung & $\mathrm{t}$ tabel & Sig t \\
\hline$\left(\mathrm{X}_{1}\right)$ & 3,132 & & 0,002 \\
$\left(\mathrm{X}_{2}\right)$ & 2,817 & 2,000 & 0,004 \\
$\left(\mathrm{X}_{3}\right)$ & 3,623 & & 0,001 \\
\hline
\end{tabular}

Sumber: Data primer diolah, 2018

Hasil perhitungan uji $t$ untuk menganalisis pengaruh variabel pengetahuan $\left(\mathrm{X}_{1}\right)$, variabel pemahaman $\left(\mathrm{X}_{2}\right)$ dan variabelkesadaran $\left(\mathrm{X}_{3}\right)$ terhadap pajak kos $(\mathrm{Y})$ pada pemilik usaha kos di Kecamatan Lowokwaru Kota Malangyaitu:

1. Variabel pengetahuan $\left(\mathrm{X}_{1}\right)$ berpengaruh terhadap variabel pajak kos (Y) pada pemilik usaha kos di Kecamatan Lowokwaru Kota Malang sebesar $(3,132)$ $<\left(t_{\text {tabel }} 2,000\right)$ dengan nilai signifikan sebesar 0,002 sehingga menerima $\mathrm{H}_{1}$

2. Variabel pemahaman $\left(\mathrm{X}_{2}\right)$ berpengaruh terhadap variabel pajak kos (Y) pada pemilik usaha kos di Kecamatan Lowokwaru Kota Malang sebesar $(2,817)$ 
$<\left(t_{\text {tabel }} 2,000\right)$ dengan nilai signifikan sebesar 0,004 sehingga menerima $\mathrm{H}_{2}$

3. Variabel kesadaran $\left(\mathrm{X}_{3}\right)$ berpengaruh terhadap pajak kos (Y) pada pemilik usaha kos di Kecamatan Lowokwaru Kota Malang sebesar(3,623) < $\left(\mathrm{t}_{\text {tabel }} 2,000\right)$ dengan nilai signifikan sebesar 0,001 sehingga menerima $\mathrm{H}_{3}$

\section{PEMBAHASAN}

Berdasarkan hasil analisis yang telah disajikan dalam penelitian ini diketahui bahwa secara parsial (masing-masing) pengetahuan berpengaruh terhadap pajak kos sebesar $(3,132)$, pemahaman berpengaruh terhadap pajak kos sebesar $(2,817)$ dan kesadaran berpengaruh terhadap pajak kos sebesar (3,623). Secara keseluruhan pengetahuan, pemahaman dankesadaran berpengaruh terhadap pajak kos pada pemilik usaha kos di Kecamatan Lowokwaru Kota Malang sebesar $61,2 \%$.

Pengetahuan yang berpengaruh terhadap pajak kos seperti Wajib Pajak Kos mengetahui cara pembayaran pajak, mengetahui jumlah pajak yang harus di bayar dan mengetahui sanksi pajak sehingga patuh membayar pajak kos. Menurut Muslim (2007) mengatakan bahwa semakin tinggi tingkat pengetahuan Wajib Pajak terhadap peraturan kemungkinan wajib pajak patuh terhadap peraturan Pajak. Tingkat pengetahuan Wajib Pajak merupakan suatu kondisi dimana wajib pajak mengetahui, menghargai dan menanti ketentuan perpajakan yang berlaku serta memiliki kesanggupan dan kemauan untuk memenuhi kewajiban perpajakannya.

Menurut Mardiasmo (2011), pengetahuan yang berpengaruh terhadap kepatuan Wajib Pajak Kos seperti mengetahui peraturan perpajakan, mengetahui cara pembayaran pajak, mengetahui pengisian SPT dengan benar, mengetahui denda atau sanksi pajak dan mengetahui manfaat pembayaran pajak sehingga meningkatkan kepatuan Wajib Pajak. Pengetahuan Wajib Pajak terhadap peraturan pajak sebagai cara menumbuhkan kepatuhan dalam pembayaran pajak sehingga wajib pajak tidak terlambat dalam pelaporan pajak. Wajib Pajak yang mengetahui peraturan pajak yang berlaku di Indonesia diharapkan akan meningkatkan kepatuhan dalam pembayaran pajak.

Pemahaman yang berpengaruh terhadap pajak kos seperti Wajib Pajak Kos mengetahui manfaat pembayaran pajak untuk membangun Kota Malang sehingga patuh dalam pembayaran pajak. Pemahaman Wajib Pajak sebagai pandangan wajib pajak pada pengetahuan perpajakan yang dimiliki. Menurut Soemitro (2011) tingkat pemahaman wajib pajak atas perpajakan dapat diukur berdasarkan pemahaman wajib pajak pada kewajiban menghitung, membayar, dan melaporkan pajak terhutang.

Pemahaman Wajib Pajak terhadap peraturan pajak sebagai cara menumbuhkan kepatuhan dalam pembayaran pajak sehingga wajib pajak tidak terlambat dalam pelaporan pajak. Wajib Pajak yang pemahaman terhadap 
peraturan pajak yang berlaku di Indonesia diharapkan akan meningkatkan kepatuhan dalam pembayaran pajak. Menurut Antikasari (2011), menjelaskan pemahaman Wajib Pajak terhadap peraturan pajak yang akan diterapkan oleh pemerintah dapat menunjang keberhasilan pemungutan pajak yang tentunya akan mengurangi tingkat pelanggaran terhadap peraturan perpajakan.

Kesadaran yang berpengaruh terhadap pajak kos seperti wajib pajak melakukan pembayaran pajak tepat waktu, sesuai dengan jumlah yang harus dibayar dan tidak pernah mendapatkan surat teguran pajak. Kesadaran Wajib Pajak sebagai perilaku atau pandangan dan perasaan yang melibatkan pengetahuan, keyakinan, dan penalaran disertai kecenderungan untuk bertindak sesuai peraturan yang diberikan oleh sistem dan ketentuan pajak tersebut sehingga melakukan pembayaran pajak tepat waktu. Kesadaran wajib pajak terhadap kepatuan wajib pajak seperti mendaftarkan diri menjadi wajib pajak tanpa paksaan, membayar pajak tepat waktu dan pembayaran pajak sesuai dengan jumlah pajak yang seharusnya dibayar.

Kesadaran Wajib Pajak dalam membayar pajak memiliki arti keadaan dimana seseorang mengetahui, memahami, dan mengerti tentang cara membayar pajak. Seiring dengan meningkatnya pemahaman tentang perpajakan dan pelayanan fokus yang baik akan berpengaruh terhadap kesadaran membayar pajak. Menurut Mardiasmo (2011), menyatakan bahwa kesadaran perpajakan masyarakat yang rendah seringkali menjadi salah satu sebab banyaknya potensi pajak yang tidak dapat dijaring. Peran aktif pemerintah untuk menyadarkan masyarakat akan pajak sangat diperlukan baik berupa penyuluhan, sosialisasi rutin atau pun berupa pelatihan secara rutin. Kesadaran yang mempengaruhi kepatuan Wajib Pajak Kos seperti wajib pajak mengetahui manfaat pembayaran pajak bagi peningkatan pembangunan daerah, mengetahui cara membayar pajak dan melakukan pembayaran Pajak tepat waktu.

Kesadaran wajib pajak adalah suatu kondisi dimana wajib pajak mengetahui, menghargai dan menanti ketentuan perpajakan yang berlaku serta memiliki kesanggupan dan kemauan untuk memenuhi kewajiban perpajakannya (Nugroho, 2011). Wajib pajak yang memiliki kesadaran yang rendah cendrung untuk tidak mematuhi kewajiban perpajakannya dan melanggar peraturan perpajakan yang berlaku. Diperlukan kesadaran yang berasal dari diri wajib pajak itu sendiri akan arti dan manfaat dari membayar pajak tersebut, masyarakat harus sadar bahwa kewajiban membayar bukanlah untuk pihak lain, tetapi untuk melancarkan jalannya roda pemerintahan yang mengurusi segala kepentingan rakyat.

Tarif Pajak Hotel untuk objek pajak jenis rumah kos dengan jumlah kamar lebih dari 10 (sepuluh) ditetapkan sebesar 5\% (lima persen). Menurut Peraturan Daerah Kota Malang Nomor 16 Tahun 2010 tentang Objek 
Pajak Hotel adalah pelayanan yang disediakan oleh hotel dengan pembayaran, termasuk jasa penunjang sebagai kelengkapan hotel yang sifatnya memberikan kemudahan dan kenyamanan, termasuk fasilitas olah raga dan hiburan termasuk motel, losmen, rumah penginapan, rumah kos, dan kegiatan usaha lainnya yang sejenis. Tindakan untuk meningkatkan pendapatan pajak kos yaitu dengan memberikan penyuluhan tentang manfaat pajak dan peraturan pajak kos sehingga wajib pajak patuh membayar pajak.

Hasil penelitian ini sesuai dengan penelitian yang dilakukan oleh Karlina (2017), membuktikan bahwa pelaksanaan pemungutan Pajak Rumah Kos mampu meningkatkan Pendapatan Asli Daerah didasarkan oleh adanya kesadaran untuk mambayar pajak, serta pengetahuan dan pemahaman Wajib Pajak yang baik tentang peraturan pajak serta manfaat pajak bagi perkembangan daerah. Wajib Pajak Kos yang patuh adalah Wajib Pajak yang taat dan memenuhi serta melaksanakan kewajiban perpajakannya sesuai dengan ketentuan peraturan perundang-undangan perpajakan.

\section{KESIMPULAN}

Berdasarkan uraian yang telah dipaparkan maka dapat disimpulkan bahwa:

1. Pengetahuan berpengaruh signifikan dan positif terhadap pajak kos di Kecamatan Lowokwaru Kota Malang. Pengetahuan yang berpengaruh terhadap pajak kos seperti Wajib Pajak Kos mengetahui cara pembayaran pajak, mengetahui jumlah pajak yang harus dibayar dan mengetahui sanksi pajak sehingga patuh membayar pajak kos.

2. Pemahaman berpengaruh signifikan dan positif terhadap pajak kos di Kecamatan Lowokwaru Kota Malang. Pemahaman yang berpengaruh terhadap pajak kos seperti Wajib Pajak Kos mengetahui manfaat pembayaran pajak untuk membangun Kota Malang sehingga petuh dalam pembayaran pajak.

3. Kesadaran berpengaruh signifikan dan positif terhadap pajak kos di Kecamatan Lowokwaru Kota Malang. Kesadaran yang berpengaruh terhadap pajak kos seperti wajib pajak melakukan pembayaran pajak tepat waktu, sesuai dengan jumlah yang harus di bayar dan tidak pernah mendapatkan surat teguran pajak.

\section{DAFTAR PUSTAKA}

Antikasari. 2011. Prosedur Kebijakan Perpajakan. Jakarta: Rineka Cipta.

D, Ananda. P. R. 2015. "Pengaruh Sosialisasi Perpajakan, Tarif Pajak, Dan Pemahaman Perpajakan Terhadap Kepatuhan Wajib Pajak" Jurnal Perpajakan (JEJAK). Vol 6 No. 2.

F, Prawagis. D. 2016. "Pengaruh Pemahaman Atas Mekanisme Pembayaran Pajak, Persepsi Tarif Pajak dan Sanksi Pajak Terhadap Kepatuhan Wajib Pajak UMKM” Jurnal Perpajakan (JEJAK) Vol. 10 No. 2

Karlina. 2017. "Pengaruh Pemahaman Peraturan Perpajakan, Tarif Pajak dan Asas Keadilan Terhadap Kepatuhan 
Wajib Pajak" Jurnal Perpajakan. Vol. 8 No. 1

Mardiasmo. 2011. Perpajakan. Yogyakarta: Andi Offset.

Nugroho. 2011. Kewajiban Perpajakan Bagi Badan Usaha. Yogyakarta: BPFE.

Soemitro, Rochmat. 2011. Asas dan Dasar Perpajakan 1 dan 2. Bandung: Eresco. 